\title{
Secrets from the editorial board room: what we like, don't like and would like to see in the Revista Portuguesa de Clínica Geral
}

John Yaphe*

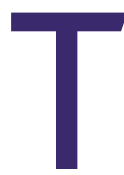

he new editorial board of the Revista Portuguesa de Clínica Geral (RPCG) is proud to present its third issue as the guiding team at the helm. After many hours of discussion in person, by phone and by electronic mail, we have begun to develop an effective modus operandi to produce a journal that is fresh, interesting, readable, enjoyable and challenging to its readers. In order to help this process along we would like to share the results of our deliberations with our readers. Perhaps my title is misleading. These are open secrets. By clarifying their meaning, we will help improve our journal.

\section{WHAT WE LIKE}

In an earlier editorial on peer review, ${ }^{1}$ we described the FINER criteria of Hulley and Cummings used to assess a research question. ${ }^{2}$ These refer to a question that is feasible, interesting, new, ethical and relevant. Editors use these criteria when first looking at a new manuscript. A so-called "hanging committee" makes a rapid decision if it is worth sending a paper out for peer review or if we must regretfully reject a manuscript and suggest that the authors consider submission elsewhere. So, to begin, we like submissions that are new, interesting, reproducible, relevant and ethical. Our overall aim is to improve family practice in Portugal and advance the scientific discipline. We believe that good publications can help to do this.

*MD, Associate Professor, School of Health Sciences, University of Minho.
We like new topics. The field of general practice is wide and encompasses almost all of human experience. It is not entirely clear why so many submissions are about risk factors of cardiovascular disease or routine maternal and child care, though we have our suspicions why these manuscripts arrive so often. A manuscript with a fresh look at commonly encountered general practice problems such as migraine, back pain, respiratory infection, or anxiety tends to generate interest and enthusiasm in the editorial team.

Another thing we like is outcome studies. We get plenty of cross-sectional studies because they are easier to do. A good longitudinal study that follows patients over time and tells us what happens to them, what worked, and what did not work is a pretty good bet to be submitted for review.

We certainly like intervention studies. These are extremely rare in this journal. It does not have to be a randomized controlled trial of a new drug and perhaps these studies are best performed by others and reviewed by other journals. However innovative family doctors can collect data on new interventions that can be compared with standard care.

\section{WHAT WE DON'T LIKE}

This could turn out to be a very long list but since we don't like long, wordy articles I will stick to our guidelines and keep this brief.

First we dislike many of the old-fashioned narrative reviews we receive. The new method of systematic reviews 
has captured our attention and respect, so old style text book articles are rarely accepted or even sent out for review. In the board room we say these articles are typical of the "throwaway" journals that fill our mailboxes. Many of these articles are thinly disguised advertisements for drugs without a truthful statement of conflict of interest by the authors and we don't like that either.

We dislike many of the so-called quality studies that also flooded our inbox for a while. The SQUIRE criteria are an excellent guideline for this kind of work. ${ }^{3}$ Quality projects are a form of research and need to follow the rules of hypothesis generation, sampling, statistical analysis and determination of cause and effect. Studies that don't close the quality loop with an intervention and second look are not interesting and not likely to be published. Perhaps we need to disseminate our guidelines in the classrooms of the quality courses given in the residency schemes around the country. Many of the submissions we receive look like reports of classroom exercises that don't follow the guidelines.

We appreciate the contributions received from hospital specialists or trainees from other disciplines but we hope that they will respect the unique environment in which we work in primary care. Selection bias often affects the case mix and study samples described in their papers. We would hope they would take this into account when making recommendations to family doctors. While we also value the approach and the style of scientific used in other specialities, we often ask ourselves if their manuscripts would be considered for publication or even review in their own speciality journals. The answer is often negative. The relationship between primary care and other specialties is an important area of study and we would welcome more original research on this aspect of health care.

Finally we dislike manuscripts that flagrantly ignore our instructions for authors. Long, disorganized articles with poor spelling and grammar raise immediate questions about the publishable potential of a manuscript. Authors are advised to pay close attention to our guidelines.

\section{WHAT WE WOULD LIKE TO SEE}

We would really like to see a fresh crop of manuscripts, on new topics relevant to general practice that have the potential to improve practice and the health of our patients. We would like to see more research done by the older experienced members of our profession. Most submissions are by trainees. While these are to be encouraged, they lack the polish and perspective of experienced family doctors. We would like to see more interventions and more outcome studies as mentioned above. We would like to see quality improvement studies that really make a difference in practice and are not just running after performance indicators. We want to see critical reviews of existing literature and not just "CV chasing" by eager trainees.

We feel we have taken some important steps forward in the first three issues as an editorial team We look forward to working with you in the next three years to make this an education, enjoyable and innovative journal.

\section{CONFLICT OF INTEREST STATEMENT}

The author is a member of the editorial board of RPCG, a peer-reviewed journal, and has written and reviewed for peer-reviewed journals.

\section{REFERENCES}

1. Yaphe J. Rethinking peer review: an empty slate. Rev Port Clin Geral 2011 May-Jun; 27 (3): 259-60.

2. Hulley SB, Cummings SR, Browner WS, Grady DG, Newman TB. Designing Clinical Research. 3rd ed. Philadelphia, PA: Lippincott, Williams \&Wilkins; 2007. p. 19-22.

3. Heleno B, Pinto D. Para além da avaliação de qualidade. Rev Port Clin Geral 2010 May-Jun; 26 (3): 244-6.

\section{ENDEREÇO PARA CORRESPONDÊNCIA}

yonahyaphe@hotmail.com

\section{CORRECÇÃO}

«O que ocupa os médicos de família? Caracterização do trabalho médico para além da consulta». Neste artigo de Mónica Granja e Carla Ponte (Rev Port Clin Geral 2011;27:388-96) foi, por lapso editorial, omitido o seguinte texto:

As autoras agradecem a colaboração dos médicos de família que participaram no estudo: Dra. Andreia Cerejo, Dr. António Macedo, Dra. Carla Nina, Dra. Carmo Novais, Dra. Ilda Gonçalves, Dr. Jaime Correia de Sousa,
Dra. Joana Santos, Dra. Mariana Tudela, Dra. Raquel Braga, Dra. Sílvia Henriques e Dra. Teresa Pinto Carneiro.

Agradecem ainda ao Dr. Jaime Correia de Sousa pela revisão crítica do manuscrito."

A Revista Portuguesa de Clínica Geral pede desculpas aos médicos de família visados e informa que o texto omitido foi agora incluído na versão on-line do artigo (http://www.apmcg.pt/PageGen.aspx? WMCM_PaginaId=33568\&artId=1074). 